\title{
THE HESPERIDE OF THE OLYMPIAN METOPE AND A MARBLE HEAD AT MADRID.
}

\section{Plate XLV.}

The marble head (Pl. XLV. 2) in the Museum of Madrid has elicited considerable notice, especially because of its peculiar style; and its attempted classification in this respect has produced much difference of opinion. Hübner, who first ${ }^{1}$ supposed it to be the head of Athene and then ${ }^{2}$ of an Aphrodite, thought that it must be a marble copy of a bronze original beloriging to the age of Pheidias. Friedrichs ${ }^{3}$ considered it to belong to the type of Aphrodite heads, but did not feel in a position to assign to it a definite date. He says: 'It decidedly gives the impression of an Hellenic work, but for the more exact dating we have no sound ground to go upon. We should only like to remark that it does not appear to us to be older than the fourth century, because it no longer contains traces of the severer style.'

We can well appreciate the difficulties that must have been felt in connexion with this head, before some well identified work was found with which it had some definite relation, and with which it could be compared. The peculiar treatment of the hair, especially the contrast between the undulations of the tresses at the side and the smoothness of the crown, the simple, almost severe character of the whole head with the breadth of later feeling commingled with the severity, are elements that would baffle the inquirer and the combination

1 Nuove Memorie dell' Instituto di Correspondenza Archeologiva (Rome, 1865) pp, 34 seq.

2 Die Antiken von Madrid, p. 247.
${ }^{8}$ Bausteine zur Geschichte der Griechisch-Römischen Plastit, ii. pp. 271, seq. 

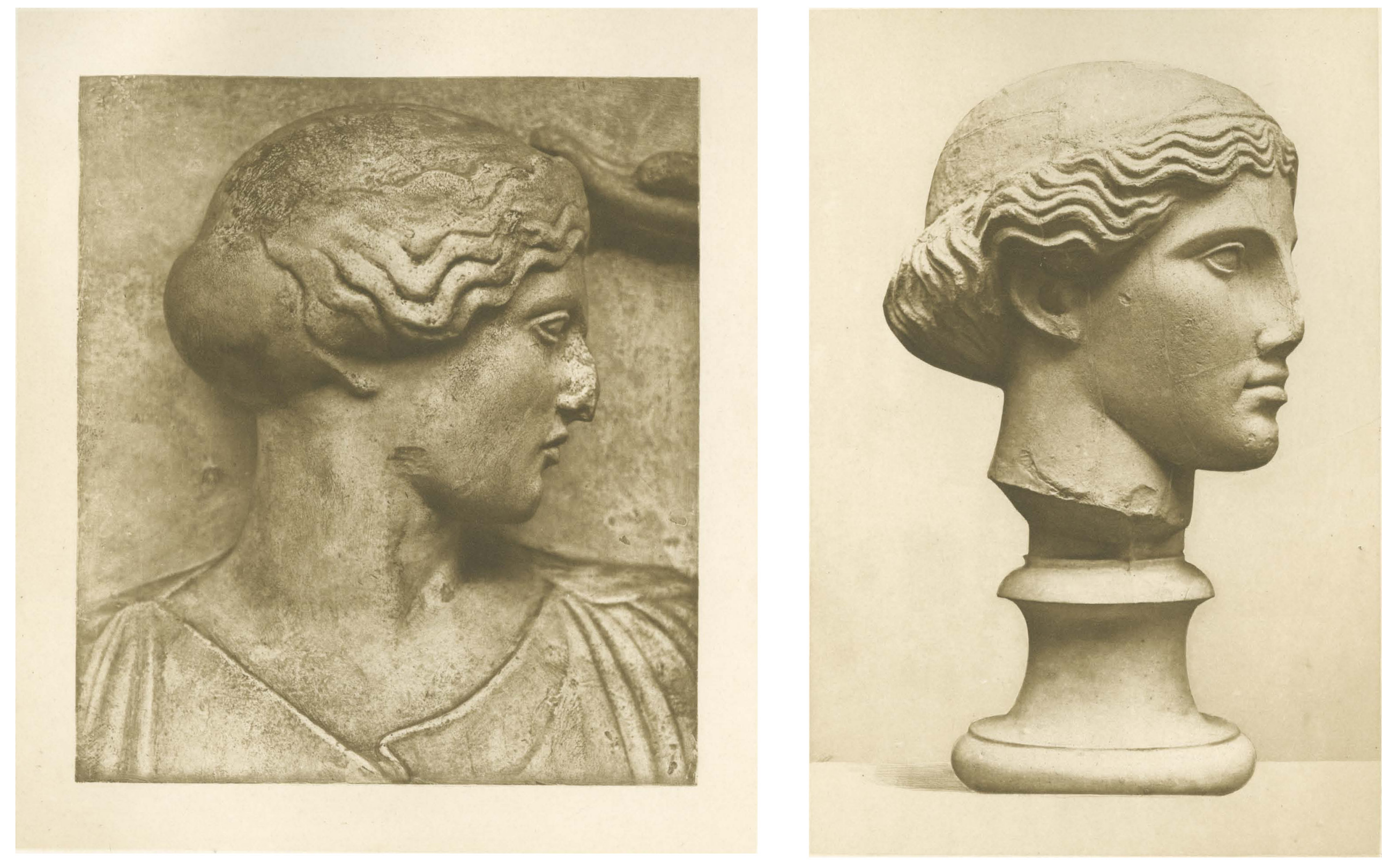
of these in one work will be accounted for in the course of these observations.

The identified work which furnishes the needed point of comparison for the placing of this head is the so-called Atlas metope from the east side of the Temple of Zeus at Olympia. The head of the 'Hesperide' standing behind Herakles in this metope $^{1}$ is here figured on plate XLV., fig. 1 , and is placed beside the Madrid head for comparison.

Unfortunately the photographic negative for M. Dujardin's plate, taken from the casts in the Fitzwilliam Museum of Classical Archaeology at Cambridge, was made during my absence, and my directions that both heads should be taken from exactly the same point of view were not quite carried out. The heavy cast of the metope is also somewhat high on the wall, which made the task of taking such a photograph more difficult. The apparent similarities between the two heads in our plate are therefore not so great as they are in reality. Furthermore I would remark that the peculiar breakage and smudging of the nose in the head from the metope, give a definite character to the head which it was far from having when complete.

It will be seen at a glance that the very uncommon arrangement of hair is the same in both instances, especially with regard to the mixture of seulptured ridges in the sides and a flat surface on the top. There can hardly be any doubt that the flat surfaces were painted over with the indications of hair. In the case of the metope head, the roll at the back of the head is also left flat, while in the Madrid head it is modelled. It is most interesting to note that Hübner, who first wrote on this head, remarked in his first paper ${ }^{2}$ upon a certain similarity between the Madrid head and the head of another figure from the Olympian metopes. The fragment of this metope together with the upper part of the metope representing Herakles and the bull, as well as several smaller fragments, had been discovered by the French in the Expedition de la Morée, in the year 1829, and have since been in the Louvre. ${ }^{3}$ This head of

1 Ausgrabungen zu Olympia vol. จ.;

2 Nuove Memorie d. Inst. l.c.

Cf. Bötticher, Olympia \&c. p. 285 ; Overbeck, Gesuh. d. Griech. Plastik, i. p. 445 .

3 Dubois and Blouet, Expédition Scientifique de la Moré, i. Pl. 74-78; Clarac, Muséc de Seulpture, vol, ii. Pl. 
the 'nymph' or 'Athene' possesses to a far less striking degree the points of similarity with the Madrid head than does the metope head with which we are comparing it. But it is remarkable that, while in the female head from the Atlas metope, the braids at the side are modelled with ridges and the crown and the braid at the back (modelled in the Madrid head) are smooth, the hair of Huibner's nymph from the other metope is worked smoothly, whilst it is here the mass at the back of the head which is the only modelled part of the hair. The fact that Hiibner should have noticed the similarity of the Madrid head with another head from the Olympian metopes possessing far less marked points of similarity to it than does the head from the Atlas metope, seems to me a strong confirmation of the relation of general style which I see between the Madrid and the Olympian heads.

Were our illustration of the Olympian head taken more from the front of the figure, this general similarity of style would be much more evident. It would then be seen how similar is the treatment of the face, of mouth and chin, how the hair parts symmetrically from the middle of the brow and runs in parallel undulations towards the sides. It must also be remembered that the metope was meant to be seen from far below, while the Madrid head was no doubt calculated to be seen from relatively a much shorter distance, and that thus the metope head would have to be treated with less detail especially in the broader ridges of the hair.

Before proceeding to dwell upon some of the numerous points of difference subsisting between the two heads we are comparing, I should like to draw attention to a fact to which I have already. alluded on another occasion (see this Journal, Vol. II. No. 2, 1881, p. 349). When two monuments with great points of similarity are singled out from the vast number of ancient monuments and are placed side by side, this isolation and juxtaposition (in itself, unconsciously to the observer, claiming a great degree of similarity) tends to bring out the points of difference to a marked and exaggerated degree to those who have not the vast number of essentially different monuments of

105в ; Müller-Wieseler, Denkmäler $d$. Alten Kunst, i. taf. 30 ; and in their complete condition: Ansgrabungen $\approx u$
Olympia, v. ; Overbeck, Oesch. d. Gr. Plastik, i. $442 ;$ A. Bötticher. Olympia, p. 279 . 
ancient art to fall back upon. People are then (this similarity being already claimed and self-asserted by the very juxtaposition) only conscious of and engrossed by the points of difference. If the monuments compared will to any degree stand this test their primary similarity is insured. To appreciate the similarity between these two heads, it is best to compare them in a museum containing a large and varied number of monuments from all schools and times. The essential difference of all other monuments will bring out the inner relation of the two and will make up, to the non-specialist, for the acquaintance with the great number of individual monuments which are ever present in the mind of the specialist.

In their general aspect the two heads differ in that the work of the Madrid head is harder and more mechanical; and though the sculptor of the Madrid head endeavoured to give a broad and severe treatment, which is a general characteristic of earlier works, his knowledge of details led him to deal more correctly with the definite features of the human head, such as the eye and ear. While the brow and cheek are harder and less naturalistic in the Madrid head than in the head of the metope, the treatment of the eye evinces knowledge and study of the most delicate forms which the Olympian sculptor had not yet attained. The ridges of the hair are decided and sharp in the Madrid head, while in the head of the metope they are rounded off as is characteristic of both hair and drapery of all the figures, also in the pediments, of this Temple. The forms of the cheekbone are clearly indicated beneath the surface in the metope head, and the depression between the cheek-bone and the risorius is more pronounced than in the harder and broader treatment of the cheek in the Madrid head.

The whole eye is more prominent in this head (as well as in all other heads from the Olympian Temple) than in the Madrid head. The eyelids join completely at either angle; while in the Madrid head is manifested a delicate study of life in that the upper eyelid projects and is prolonged over the under eyelid at their juncture at the side. All the heads from the Temple of Zeus at Olympia have the same characteristic treatment. In fact this detail seems to mark the line between the works before and after about the year 450 before our era. So far as I have been able to examine the point at present, the heads 
from the metopes of the Parthenon have the same early treatment of the eye as the Olympian sculptures; while the extant heads from the frieze of the Parthenon have the later treatment of the eye. ${ }^{1}$ On the whole, we must feel in the eye of the Madrid head, despite the attempted simplicity, certain characteristics which mark the works of the fourth century, and it is the effect of this detail which must have driven so excellent an observer as was Friedrichs to consider it impossible to place the head earlier than the fourth century. On the other hand, there are elements of hardness and severity in the head which direct us towards the early part of the fifth century, where Huibner would place the head. But this hardness is not only due to [attempted] simplicity of style, but also to the more mechanical working of the marble to which allusion has been made above.

Without being one of the late Roman shop-copies and imitations, turned out by the dozen during the decline of classical art, specimens of which fill our museums, the Madrid head bears traces of this more hasty and mechanical workmanship as compared with the individuality of modelling in the metope head. The general sentiment displayed in the treatment of the eye, as well as the fuller knowledge of details belies its origin in the fifth century; while its evident immediate relation to the head from Olympia, as well as the severity and simplicity of composition, belies its origin in the fourth century.

It thus appears to me to be a direct derivative from the heads of the class to which belongs the head at Olympia, made after the fourth century in the period of Graeco-Roman Renaissance by the sculptors in the first century before our era, who reproduced, or were influenced by, the works of earlier Greek art and to whom so much attention has been drawn of late years.

\section{Charles Waldstein.}

1 This detail may prove of some importance in determining the chronological relation between the sculptures of the Olympian pediment and those of the Parthenon, as well as in determining the exact chronology between the Parthenon sculptures among each other. 